\title{
Characterization of chicken natural resistance-associated macrophage protein encoding genes (Nramp1 and Nramp2) and association with salmonellosis resistance
}

\author{
X.M. He ${ }^{1,2}$, M.X. Fang ${ }^{3}$, Z.T. Zhang ${ }^{1,2}$, Y.S. Hu ${ }^{1,2}$, X.Z. Jia ${ }^{1,2}$, D.L. He ${ }^{1,2}$, \\ S.D. Liang ${ }^{1,2}$, Q.H. Nie ${ }^{1,2}$ and X.Q. Zhang ${ }^{1,2}$ \\ ${ }^{1}$ Department of Animal Genetics, Breeding and Reproduction, \\ College of Animal Science, South China Agricultural University, \\ Guangzhou, Guangdong, China \\ ${ }^{2}$ Guangdong Provincial Key Lab of Agro-Animal Genomics and Molecular Breeding, \\ Guangzhou, Guangdong, China \\ ${ }^{3}$ Department of Laboratory Animal Science, \\ Medical College of Jinan University, Guangzhou, Guangdong, China \\ Corresponding author: Q.H. Nie \\ E-mail: nqinghua@scau.edu.cn \\ Genet. Mol. Res. 12 (1): 618-630 (2013) \\ Received March 21, 2012 \\ Accepted August 10, 2012 \\ Published January 30, 2013 \\ DOI http://dx.doi.org/10.4238/2013.January.30.5
}

\begin{abstract}
Natural resistance-associated macrophage protein 1 and 2 encoding genes (Nramp1 and Nramp2) are related to many diseases. We cloned the cDNA of chicken Nramp1 and Nramp2 genes, characterized their expression and polymorphisms, and investigated the association of some SNPs with resistance to salmonellosis. The Nramp1 cDNA was 1746 bp long and the Nramp2 cDNA was 1938 bp long. These cDNAs are similar to previously reported cDNAs, varying by two and one amino acids, respectively. The chicken Nrampl gene expressed predominantly in liver, thymus and spleen in both females and males. The Nramp 2 gene expressed in almost all tissues, but
\end{abstract}


predominantly in breast muscle, leg muscle, cerebrum, cerebellum, lung, kidney, and heart in both females and males. We identified 45 SNPs and 2 indels in the chicken Nrampl gene; three of 13 SNPs in the exons were missense mutations (Arg223Gln, Ala273Glu and Arg497Gln). Association analysis indicated that A24101991G is significantly associated with chicken salmonellosis resistance. These results will be useful for functional investigation of chicken Nramp1 and Nramp2 genes.

Key words: Chicken; Nramp1 gene; Nramp2 gene; Cloning; Expression; Polymorphism

\section{INTRODUCTION}

Homologs of natural resistance-associated macrophage protein (Nramp) or solute carrier 11 (SLC11), conserved in eukaryotes and bacteria, form a family of proton-coupled transporters that maintain divalent metal $\left(\mathrm{Me}^{2+}\right.$, including $\mathrm{Mn}^{2+}, \mathrm{Fe}^{2+}, \mathrm{Co}^{2+}$, and $\left.\mathrm{Cd}^{2+}\right)$ homeostasis (Mackenzie and Hediger, 2004; Courville et al., 2006). There are two Nramp genes that are associated with diseases in vertebrates. Nrampl (also called SLC11A1) restricts microbial access to essential micronutrients such as $\mathrm{Fe}^{2+}, \mathrm{Mn}^{2+}, \mathrm{Co}^{2+}$, and $\mathrm{Zn}^{2+}$ within professional phagosomes (Boyer et al., 2002; Jabado et al., 2000, 2003; Peracino et al., 2006; Cellier et al., 2007). It defends against various intracellular pathogens including Salmonella typhimurim, Leishmania donovani and Mycobacterium bovis (Vidal et al., 1993; Blackwell et al., 1999, 2000, 2003). Nramp2 (also known as SLC11A2, DMT1 or DCT1), expresses specifically at the apical membrane of epithelial cells or ubiquitously in recycling endosomes, plays an important role in regulating body iron levels and transports a broad range of divalent metal ions $\left(\mathrm{Cu}^{2+}, \mathrm{Mn}^{2+}, \mathrm{Co}^{2+}\right.$, and $\left.\mathrm{Pb}^{2+}\right)$ (Gunshin et al., 1997; Gruenheid et al., 1999; Tandy et al., 2000; Trinder et al., 2000; Canonne-Hergaux et al., 1999, 2002; Touret et al., 2003). Recently, it was reported that Nramp are cellular receptors for Sindbis virus in both insect and mammalian hosts (Rose et al., 2011), but this issue was elusive according to other report (Stiles and Kielian, 2011).

Both Nramp1 and Nramp2 proteins have 12 conserved transmembrane domains (TM), two N-linked glycosylation sites, and a transport motif. These conserved domains perform various important functions. Mutations within TMs are likely to be of vital consequence to organisms. In Nramp1, mice with mutation G169D within TM4 renders them susceptible to intracellular pathogens (White et al., 2004). The deletion of the residue Thr178 impairs intermolecular interactions and alters the cooperativity in proton binding of Asp14 and Asp22 (Xue et al., 2009). In Nramp2, many variations are reported to decrease $\mathrm{Me}^{2+}$ absorption, to cause protein dysfunction, and to alter functional expression (Cohen et al., 2003; Lam-Yuk-Tseung et al., 2003, 2006; Courville et al., 2006; Mackenzie et al., 2006).

Polymorphisms of Nramp genes are associated with various diseases. Polymorphisms of the human Nrampl gene [5'(GT)n, D543N, and INT4G/C (rs3731865)] are significantly associated with Crohn's disease and rheumatoid arthritis (Gazouli et al., 2008; Ates et al., 2009). A 4-bp deletion polymorphism in the 3'-UTR is related to the incidence of post-transplant lymphoproliferative disease after liver transplantation (Barshes et al., 
2006). Some polymorphisms were further identified to be associated with type 1 diabetes (T1D) (Yang et al., 2011). The association between D543N polymorphism and tuberculosis is sex- and age-dependent in Chinese (Leung et al., 2007). The (GT) ${ }_{13}$ allele of 3'-UTR was significantly associated with increased production of $\mathrm{H}_{2} \mathrm{O}_{2}$ and $\mathrm{NO}$ (Ganguly et al., 2008). In pig, a single nucleotide polymorphism (SNP) in the sixth intron of the Nrampl gene is associated with polymorphonuclear leukocyte levels, effect of cytotoxin on monocytes and 180-day-old body weight (Wu et al., 2008). In humans, the $\mathrm{C}$ allele of rs407135 in the Nramp 2 gene is related to shorter disease duration in sporadic amyotrophic lateral sclerosis patients (Blasco et al., 2011).

Until now, the variations of Nramp genes and their effects on disease have been investigated far less either in chicken or other birds. In this study, we aimed to clone Nramp1 and Nramp 2 cDNA in Chinese local chickens, to identify the expression and variations of these two genes, as well as to investigate the associations of the Nrampl gene with salmonellosis resistance.

\section{MATERIAL AND METHODS}

\section{Animals}

Three male and three female Partridge chickens were purchased from the Institute of Animal Science, Guangdong Academy of Agricultural Science (Guangdong Province, China). Each bird was slaughtered to collect 20 tissues, including cerebrum, cerebellum, hypothalamus, pituitary, breast muscle, leg muscle, subcutaneous fat, abdominal fat, thymus, heart, liver, spleen, lung, kidney, gizzard, stomachus glandularis, small intestine, cecum, cloacal bursa, testis, or ovary. All tissues were stored in a $-80^{\circ} \mathrm{C}$ freezer (Thermo Forma, USA) for long-term preservation. A total of 25 DNA samples were used to identify the polymorphisms across the whole genome of the chicken Nrampl gene. These samples were from five Chinese local populations including Qingyuan partridge, Wens partridge (WP), Guangdong partridge, Xinguang Tiejiao partridge, and Xinhua chicken with five random chickens representing each population. Two hundred WP chickens with phenotypic record of salmonellosis infection (or resistance) were used in association analysis. These samples were collected from Guangdong Wens Foodstuffs Group Co., Ltd. (Guangdong, China).

\section{Primers}

Based on the Gallus gallus mRNA sequence of the Nramp1 gene on NCBI (GenBank: NM_204964.1), the Nramp2 gene (GenBank: EF635922), the beta-actin gene ( $\beta$-actin) (GenBank: NM_205518.1), and the genomic sequence of chicken on UCSC (http://genome.ucsc.edu/ cgi-bin/hgBlat), 19 primer pairs were designed using the GeneTool Lite Launcher software (http:// www.BioTools.com/) and then synthesized by Biosune Co. Ltd. (Shanghai, China) (Table 1).

\section{cDNA and DNA preparation}

Total RNA of all tissues was isolated by Trizol (Takara Co., Japan), and then used to amplify the cDNA of chicken Nramp1 and Nramp2 genes. Total RNA of all tissues was 
reverse transcribed with the use of the PrimeScript ${ }^{\circledR}$ RT reagent kit with gDNA Eraser (Takara Co.) for real-time quantitative PCR analysis. Genomic DNA was extracted from the chicken blood with the standard phenol-chloroform method.

\begin{tabular}{|c|c|c|c|c|c|}
\hline Gene & Primer & Sequence & $\begin{array}{c}\text { Annealing } \\
\text { temperature }\left({ }^{\circ} \mathrm{C}\right)\end{array}$ & $\begin{array}{l}\text { Product size } \\
\text { (bp) }\end{array}$ & Purpose \\
\hline \multirow[t]{3}{*}{ Nrampl } & P1 & $\begin{array}{l}\text { F: 5'-ggggggatgggggctataa-3' } \\
\text { R: 5'-ccccacggcccagatgtaga-3' }\end{array}$ & 61 & 1183 & cDNA cloning \\
\hline & P2 & $\begin{array}{l}\text { F: 5'-ttcggcgaggctttctac-3' } \\
\text { R: 5'-gacggaacccatcagtgc-3' }\end{array}$ & 59 & 749 & \\
\hline & P3 & $\begin{array}{l}\text { F: 5'-cccccacatcacccegtcc-3' } \\
\text { R: } 5^{\prime} \text {-ggecccacactgcaggttgac-3' }\end{array}$ & 63 & 180 & Real-time PCR \\
\hline$\beta$-actin & P4 & $\begin{array}{l}\text { F: 5'-tggcattgctgacaggat-3' } \\
\text { R: 5'-ctgcttgctgatccacat-3' }\end{array}$ & 63 & 160 & \\
\hline \multirow[t]{4}{*}{ Nramp2 } & P5 & $\begin{array}{l}\text { F: 5'-cggcceggctgctctctacat-3' } \\
\text { R: 5'-gcagcacgcgggcaaagc-3' }\end{array}$ & 63 & 140 & \\
\hline & P6 & $\begin{array}{l}\text { F: 5'-tggggagcagagcacgga-3' } \\
\text { R: 5'-gccgggccgaagtaacag-3' }\end{array}$ & 58 & 1188 & cDNA cloning \\
\hline & P7 & $\begin{array}{l}\text { F: 5'-tgcgctcttcgtctccttcatc-3' } \\
\text { R: } 5^{\prime} \text {-tgccotcccacctccatctc-3' }\end{array}$ & 60 & 828 & \\
\hline & P8 & $\begin{array}{l}\text { F: 5'-ggcggtgcggtcatcctc-3' } \\
\text { R: 5'-cccagtgccatccccgtgt-3' }\end{array}$ & 62 & 422 & \\
\hline \multirow[t]{8}{*}{ Nrampl 1} & P9 & $\begin{array}{l}\text { F: 5'-ccccaaccccatcctctt--3' } \\
\text { R: } 5^{\prime} \text {-gcggggaacacgggcag-3' }\end{array}$ & 64 & 628 & Identification of variations \\
\hline & P10 & $\begin{array}{l}\text { F: 5'-ccggcagggtcagcaactc-3' } \\
\text { R: 5'-tcccagcttcatcccagagac-3' }\end{array}$ & 57 & 707 & \\
\hline & P11 & $\begin{array}{l}\text { F: 5'-gggctttgagtgacacctgtg-3' } \\
\text { R: 5'-ccgtttgggcatagggttagat-3' }\end{array}$ & 57 & 759 & \\
\hline & P12 & $\begin{array}{l}\text { F: 5'-cccagaaagaggcgaccagta-3' } \\
\text { R: } \text { 5'-cctgggatgcttgggagag-3' }^{\prime}\end{array}$ & 64 & 726 & \\
\hline & P13 & $\begin{array}{l}\text { F: 5'-cccatcccttccaggtgcc-3' } \\
\text { R: } 5^{\prime} \text {-ggectccttcacctcctccttc-3' }\end{array}$ & 65 & 858 & \\
\hline & P14 & $\begin{array}{l}\text { F: 5'-catcgttggtgccatcatcat-3' } \\
\text { R: 5'-cccaaaatagcagcccagga-3' }\end{array}$ & 64 & 737 & \\
\hline & P15 & $\begin{array}{l}\text { F: 5'-cccaaacccaacccctcgcta-3' } \\
\text { R: 5'-ggtcgttcatgcccgtcagct-3' }\end{array}$ & 64 & 701 & \\
\hline & P16 & $\begin{array}{l}\text { F: 5'-gcccegtcttttcccegcac-3' } \\
\text { R: } \text { 5'-cggcggtgacatcgagctga-3' }^{\prime}\end{array}$ & 65 & 844 & \\
\hline \multirow[t]{3}{*}{ Nramp1 } & P17 & $\begin{array}{l}\text { F: 5'-gggctttgagtgacacctgtg-3' } \\
\text { R: } 5^{\prime} \text {-tgccctgtgccttggtttt-3' }\end{array}$ & 63 & 490 & PCR-RFLP \\
\hline & P18 & $\begin{array}{l}\text { F: 5'-gccagcatcttccceatcaac-3' } \\
\text { R: 5'-accccaagtgaacccctctgc-3' }\end{array}$ & 63 & 461 & \\
\hline & P19 & $\begin{array}{l}\text { F: 5'-cccaaacccaacccctcgcta-3' } \\
\text { R: 5'-gggggtgcggggaaaagac-3' }\end{array}$ & 64 & 575 & \\
\hline
\end{tabular}

$\mathrm{F}$ and $\mathrm{R}$ indicate forward and reverse primers, respectively.

\section{Cloning and sequencing}

The total cDNA from liver, kidney, spleen, thymus, cecum, and cloacal bursa tissues was pooled to amplify the Nramp1 and Nramp2 genes by PCR. All required reagents were mixed according to instructions of KOD FX DNA polymerase (Toyobo, Japan). The PCR procedure was run at $94^{\circ} \mathrm{C}$ pre-denaturing for 2 min, followed by 32 cycles of $98^{\circ} \mathrm{C}$ for $10 \mathrm{~s}$, the specific annealing temperature for $30 \mathrm{~s}$ (Table 1) and $68^{\circ} \mathrm{C}$ for $2 \mathrm{~min}$, and a final extension of $10 \mathrm{~min}$ at $68^{\circ} \mathrm{C}$. PCR products were purified with the E.Z.N.A ${ }^{\circledR}$ Gel reaction kit (Omega Bio-Tek, GA, USA). After using the DNA A-Tailing kit (Takara, Co.) to add poly(A) to the 
$3^{\prime}$-terminal at $72^{\circ} \mathrm{C}$ for $20 \mathrm{~min}, \mathrm{PCR}$ products were cloned into PMD18-T vector (Takara Co.) and subsequently sent to Invitrogen Co. Ltd. (Shanghai, China) for sequencing.

\section{Homology analysis}

The cDNA and protein sequences of the Nramp1 and Nramp2 genes in various species were downloaded from NCBI (http://www.ncbi.nlm.nih.gov/) (Table S1). The protein sequences were analyzed to indicate homology and phylogenetic relationship. In this study, MegAlign of the DNASTAR software package (http://www.dnastar.com) was used to calculate the percent identities among species and to construct the phylogenetic tree.

\section{Variation analysis}

According to the genomic sequence of the chicken Nramp1 gene released by the UCSC database (http://mgc.ucsc.edu/cgi-bin/hgBlat), PCR was performed with 8 primer pairs (P9-P16). PCR products amplified from 25 DNA samples were sequenced by Invitrogen Co. Ltd. All sequences were blasted thoroughly to identify variations across the whole chicken Nramp1 gene. Partial SNPs were genotyped with the PCR-RFLP method to analyze their associations with salmonellosis resistance in chicken.

\section{Association of some SNPs with salmonellosis resistance}

Using the MapDraw program of the DNASTAR software package (http://www.dnastar. com), restriction enzymes of Bsu36I, HhaI, Bst $\mathrm{UIL}$, and $A v a \mathrm{I}$ specifically for C24103249G, A24101991G, C24098493T, and C24098282G, respectively, were used in PCR-RFLP analysis. Minor allele frequency and Hardy-Weinberg equilibrium were determined by the Plink 1.07 software (http://www.softpedia.com). Marker-trait association analysis was performed by the SAS 8.0 GLM procedure and the genetic effects were analyzed using the following model:

$$
\mathrm{Y}=\mu+\mathrm{G}+\mathrm{Pi}+\mathrm{e}
$$

where $Y$ is the observation on the trait, $\mu$ is the overall population mean, $G$ is the fixed effect of genotype, $P i$ is the fixed effect of parity, and $e$ is the residual random error. Multiple comparisons were analyzed with least squares means. Significance was considered at $P \leq 0.05$.

\section{Real-time (RT) quantitative PCR analysis}

In this study, $\beta$-actin was used as internal control and SYBR green as fluorescent dye to quantify the mRNA level of chicken Nramp1 and Nramp2 genes by RT-PCR analysis. Each sample was repeated three times. The reaction mixture contained $10 \mu \mathrm{L} 2 \mathrm{X}$ Q-PCR SYBR Green Mix (Toyobo), $0.2 \mu \mathrm{L} 10 \mu \mathrm{M}$ of each primer, $8.6 \mu \mathrm{L}$ ultrapure RNase-free water, and $1 \mu \mathrm{L}$ cDNA in a final volume of $20 \mu \mathrm{L}$. Running program was performed in a BIO-RAD CFX96 system (Bio-Rad, USA) as follows: $95^{\circ} \mathrm{C}$ for $1 \mathrm{~min} ; 40$ cycles of $95^{\circ} \mathrm{C}$ for $5 \mathrm{~s}$ and $63^{\circ} \mathrm{C}$ for $30 \mathrm{~s} ; 65^{\circ} \mathrm{C}$ for $5 \mathrm{~s}$, and $95^{\circ} \mathrm{C}$ for $5 \mathrm{~s}$, and sample values were displayed when the run was over. Melting curve analysis was performed to confirm the specificity of the product. Chicken Nramp1 and Nramp2 mRNA relative 
expression was indicated by $2^{-\Delta \Delta C t}$, where $\Delta \Delta \mathrm{Ct}$ corresponded to the difference between the $\mathrm{Ct}$ measured for the mRNA level of each tissue and the $\mathrm{Ct}$ measured for the mRNA level of the reference tissue (the gizzard in this study), $\Delta \mathrm{Ct}=\mathrm{Ct}$ (target gene) $-\mathrm{Ct}(\beta$-actin).

\section{RESULTS}

\section{Chicken Nramp1 and Nramp2 cDNA sequences}

In this study, we obtained a 1746-bp cDNA for the chicken Nrampl gene, including 67-bp 5'-UTR, 11-bp 3'-UTR and 1668-bp open reading frame encoding 555 amino acids (Figure 1). We also obtained a 1938-bp cDNA for the chicken Nramp2 gene, including 152-bp 3'-UTR and 1786-bp incomplete coding sequence encoding 594 amino acids (Figure 2). Moreover, we found that there were two single amino acid variations in the Nramp1 gene (Met8Thr and Gly81Ser) and one amino acid variation (Ala537Val) in the Nramp2 gene compared with the amino acid sequence of NP_990295.1 and ABV00877.1, respectively.

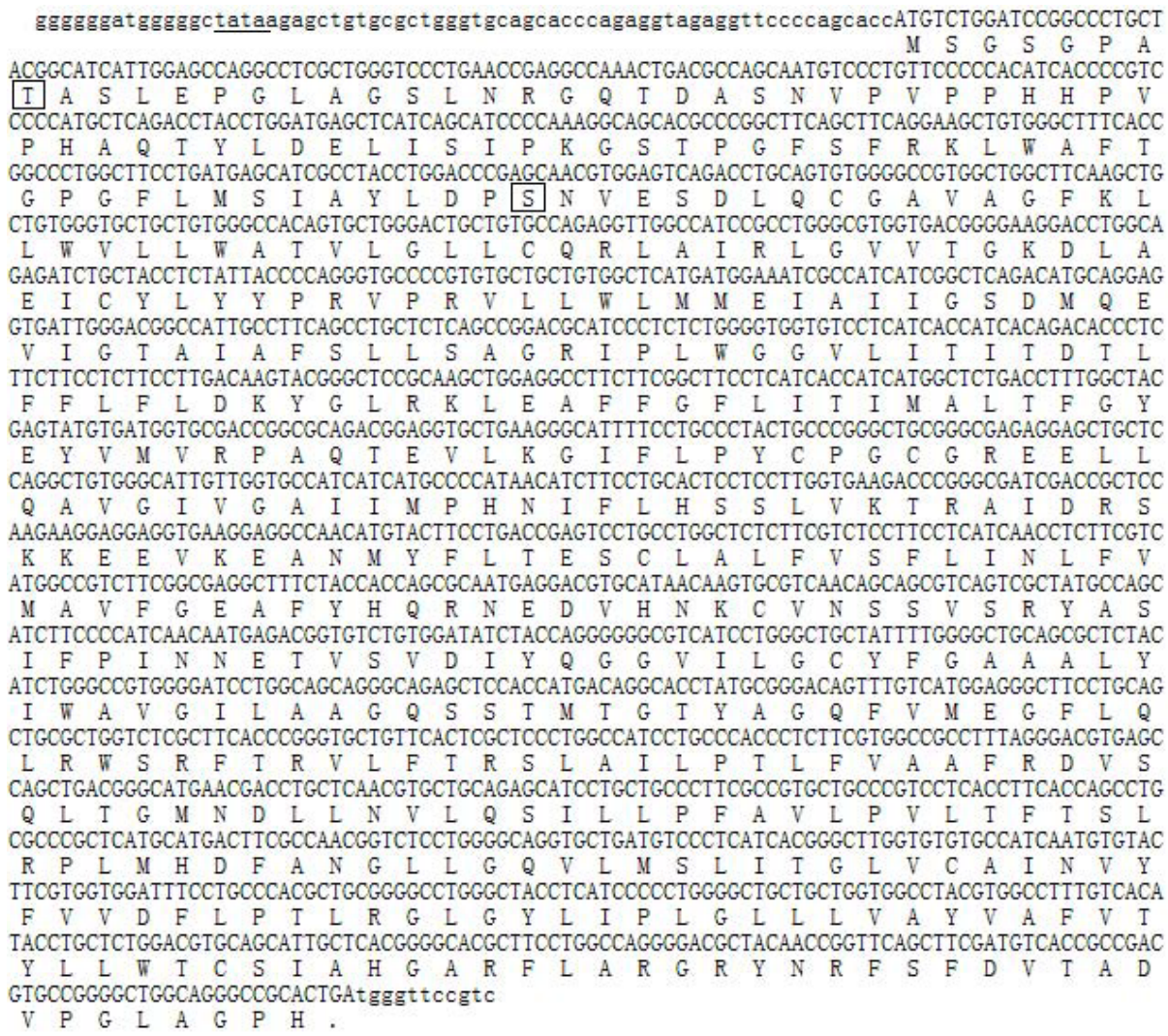

Figure 1. cDNA sequence and encoded amino acids of the chicken Nramp1 gene. Capital letters show open reading frame (ORF) and lower case letters show 5'- and 3'-UTR. Capital letters below ORF indicate amino acids for each codon upside, and "." refers to the stop codon. Underlined nucleotides indicate a "TATA" box and the boxed amino acids indicate amino acid variation compared with reported database. 


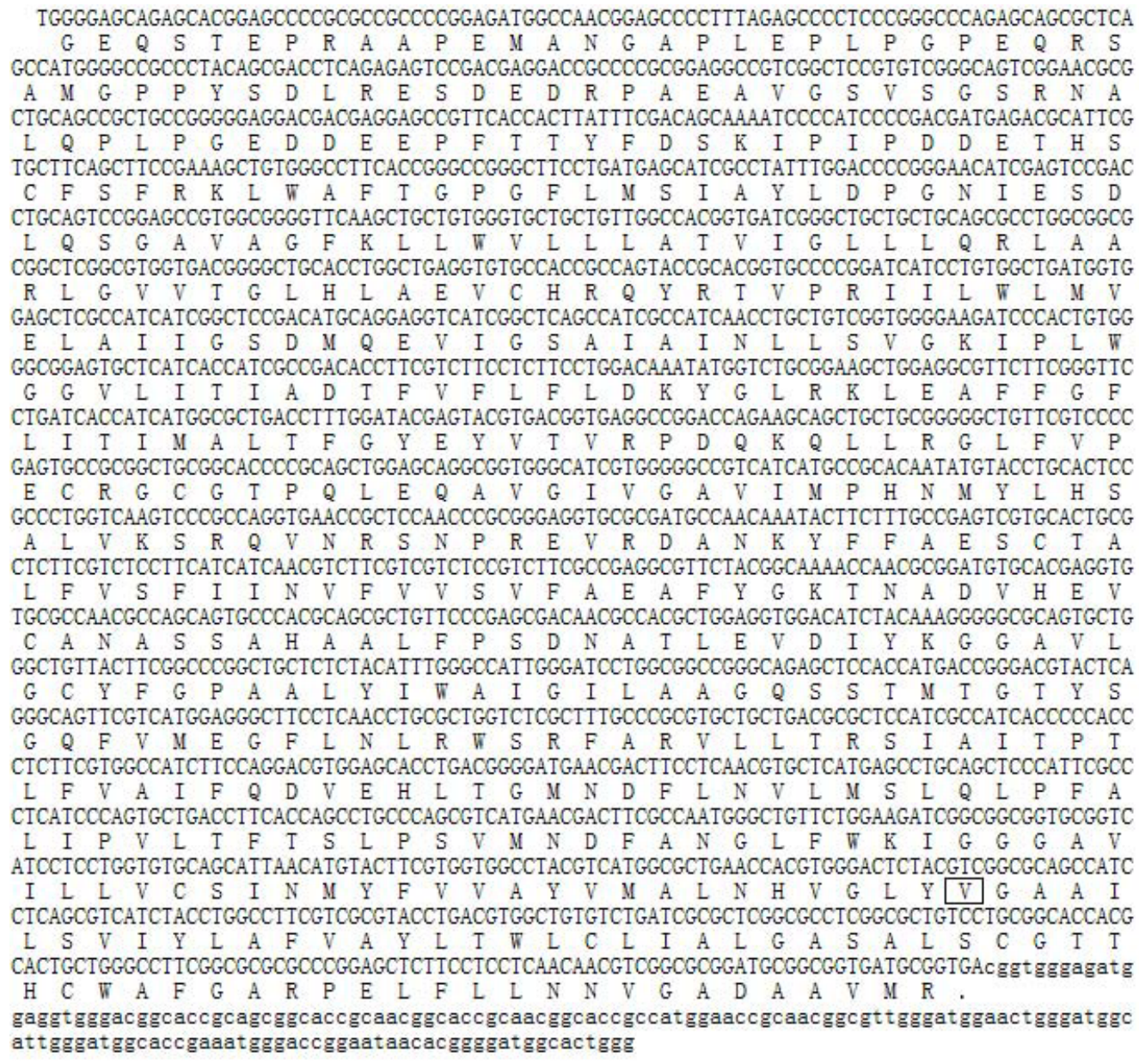

Figure 2. cDNA sequence and encoded amino acids of the Nramp2 gene. Capital letters show CDS and lower case letters show 3'-UTR. Capital letters below CDS indicate amino acids for each codon upside, and "." refers to the stop codon. The boxed amino acid indicates amino acid variation compared with reported database.

\section{Sequence analysis}

Sequence analysis revealed that the chicken Nramp1 protein shared 67.3 to $69.7 \%$ identities with mammals (human, mouse, rat, pig, dog, cattle, sheep, deer, and horse), which are lower than that with quail (96.6\%), but higher than that with fish (62.0\%) (Figure S1A). The chicken Nramp2 protein shared 77.5 to $79.6 \%$ identities with mammals (human, mouse, rat, pig, dog, cattle, and horse), and 75.2 and $76.1 \%$ identities with Danio rerio and Xenopus, respectively (Figure S1B).

The constructed phylogenetic tree of the Nramp1 protein displayed three distinct groups of mammals, avian species (quail and chicken) and fish (Figure 3A), and similar results were shown by Nramp2 homology (Figure 3B). 


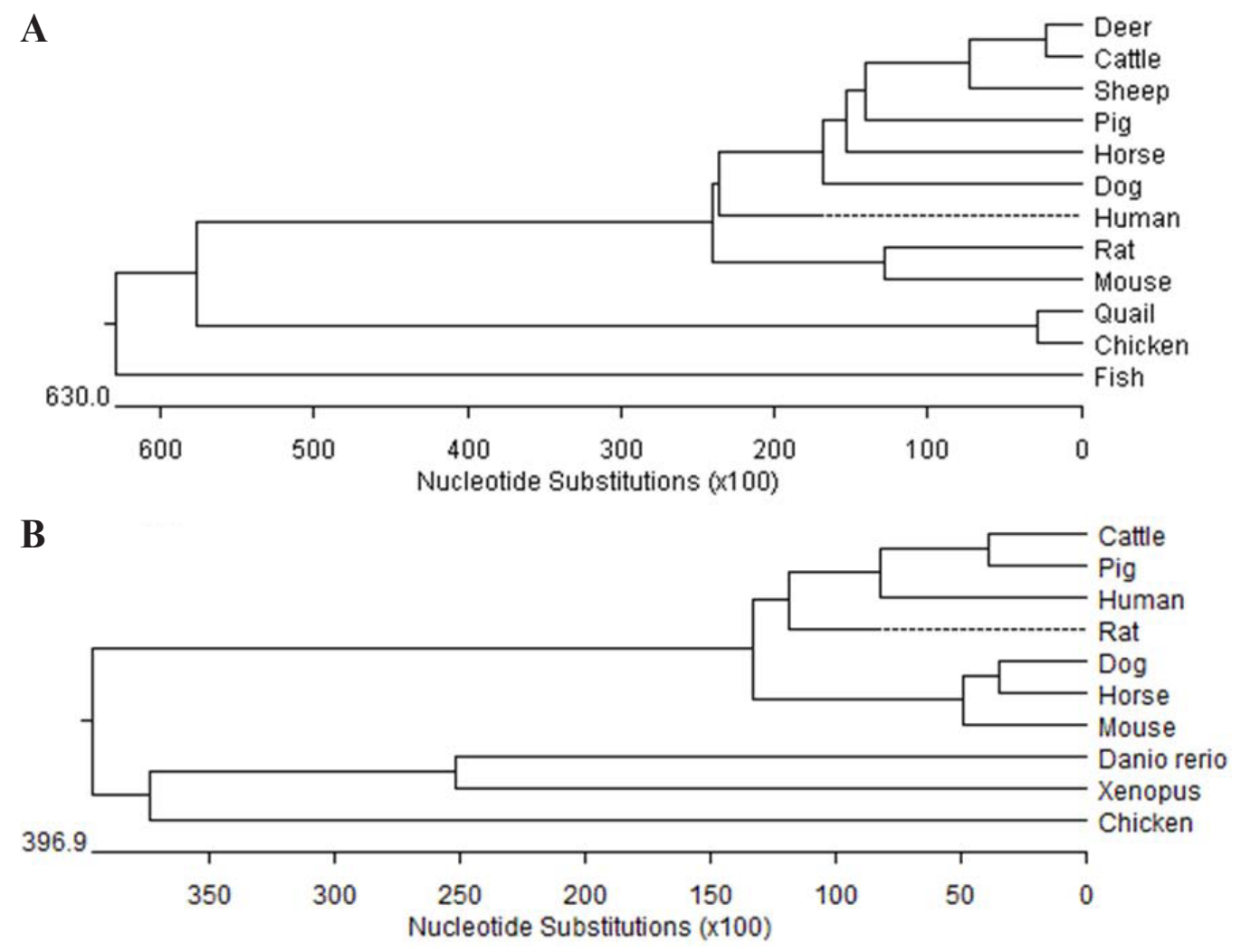

Figure 3. Phylogenetic tree among species based on Nramp1 (A) and Nramp2 (B) homologies.

\section{SNPs}

We identified in total 45 SNPs and 2 indels across the whole Nramp1 gene (Table 2). Among these SNPs and indels, 11 were located in the 5'-flanking region or 5'-UTR, 13 in the coding region (3 led to amino acid substitutions: Arg223Gln, Ala273Glu and Arg497Gln) and the rest in the intron. Moreover, 42 SNPs were PCR-RFLP markers, as they could be recognized by restriction enzymes.

\section{Association study}

Four SNPs of C24103249G, A24101991G, C24098493T, and C24098282G were used in association analysis. C24103249G was located in the 5'-flanking region, whereas A24101991G and C24098493 T were located in exons and were both synonymous mutations. In this study, the minor allele frequency for each of four SNPs was higher than 0.05. Association analysis showed that only A24101991G was significantly associated with salmonellosis resistance $(\mathrm{P}<0.05)$, and that the A allele was advantageous for salmonellosis resistance (Table 3). 
Table 2. Forty-five SNPs and two indels identified in the chicken Nramp1 gene.

\begin{tabular}{|c|c|c|c|c|c|c|c|}
\hline No. & Site & Region & SNP & No. & Site & Region & SNP \\
\hline 1 & 24103249 & 5'-flanking & $\mathrm{C}>\mathrm{G}$ & 25 & 24099597 & In6 & $\mathrm{G}>\mathrm{A}$ \\
\hline 2 & 24103055 & 5'-flanking & $\mathrm{G}>\mathrm{A}$ & 26 & 24099590 & In6 & $\mathrm{T}>\mathrm{C}$ \\
\hline 3 & 24102989 & 5'-flanking & $\mathrm{T}>\mathrm{A}$ & 27 & 24099570 & In6 & $\mathrm{A}>\mathrm{T}$ \\
\hline 4 & 24102956 & 5'-flanking & $\mathrm{T}>\mathrm{G}$ & 28 & 24099386 & Ex8 & $\mathrm{G}>\mathrm{A}$ \\
\hline 5 & 24102928 & 5'-flanking & $\mathrm{C}>\mathrm{T}$ & 29 & 24099253 & Ex8 & $\mathrm{A}>\mathrm{C}$ \\
\hline 6 & 24102891 & 5'-flanking & $\mathrm{G}>\mathrm{A}$ & 30 & 24099202 & In8 & $\mathrm{C}>\mathrm{T}$ \\
\hline 7 & 24102873 & 5'-flanking & $\mathrm{T}>\mathrm{C}$ & 31 & 24099187 & In8 & $\mathrm{G}>\mathrm{A}$ \\
\hline 8 & 24102844 & 5'-flanking & $\mathrm{T}>\mathrm{C}$ & 32 & 24099155 & $\operatorname{In} 8$ & $\mathrm{~T}>\mathrm{C}$ \\
\hline 9 & 24102650 & 5'-UTR & $\mathrm{C}>\mathrm{T}$ & 33 & 24099122 & Ex9 & $\mathrm{C}>\mathrm{A}$ \\
\hline 10 & $24102558-63$ & 5'-UTR & TCCTCC $>$ del. & 34 & 24099076 & Ex9 & $\mathrm{C}>\mathrm{T}$ \\
\hline 11 & 24102514 & 5'-UTR & $\mathrm{G}>\mathrm{A}$ & 35 & 24099049 & Ex9 & $\mathrm{G}>\mathrm{C}$ \\
\hline 12 & 24101991 & Ex2 & $\mathrm{A}>\mathrm{G}$ & 36 & 24099007 & Ex9 & $\mathrm{C}>\mathrm{T}$ \\
\hline 13 & 24101943 & $\operatorname{In} 2$ & $\mathrm{~T}>\mathrm{A}$ & 37 & 24099004 & Ex9 & $\mathrm{T}>\mathrm{C}$ \\
\hline 14 & 24101903 & $\operatorname{In} 2$ & $\mathrm{C}>\mathrm{G}$ & 38 & 24098949 & $\operatorname{In} 9$ & $\mathrm{~T}>\mathrm{G}$ \\
\hline 15 & 24101826 & $\operatorname{In} 2$ & $\mathrm{~A}>\mathrm{G}$ & 39 & 24098937 & In9 & $\mathrm{C}>\mathrm{T}$ \\
\hline 16 & 24101821 & In 2 & $\mathrm{G}>\mathrm{A}$ & 40 & 24098916 & In9 & $\mathrm{A}>\mathrm{G}$ \\
\hline 17 & 24100620 & $\operatorname{In} 2$ & $\mathrm{~T}>\mathrm{C}$ & 41 & 24098903-02 & In9 & Insert TGGATGG \\
\hline 18 & 24100562 & Ex3 & $\mathrm{C}>\mathrm{T}$ & 42 & 24098514 & Ex11 & $\mathrm{C}>\mathrm{T}$ \\
\hline 19 & 24100248 & In 4 & $\mathrm{G}>\mathrm{A}$ & 43 & 24098493 & Ex11 & $\mathrm{C}>\mathrm{T}$ \\
\hline 20 & 24100162 & In 4 & $\mathrm{G}>\mathrm{A}$ & 44 & 24098394 & In11 & $\mathrm{G}>\mathrm{A}$ \\
\hline 21 & 24100076 & In4 & $\mathrm{G}>\mathrm{A}$ & 45 & 24098282 & In11 & $\mathrm{C}>\mathrm{G}$ \\
\hline 22 & 24099838 & Ex 5 & $\mathrm{C}>\mathrm{T}$ & 46 & 24097633 & In13 & $\mathrm{T}>\mathrm{G}$ \\
\hline 23 & 24099784 & $\operatorname{In} 5$ & $\mathrm{~T}>\mathrm{C}$ & 47 & 24097516 & Ex14 & $\mathrm{G}>\mathrm{A}$ \\
\hline 24 & 24099652 & Ex6 & $\mathrm{G}>\mathrm{A}$ & & & & \\
\hline
\end{tabular}

In and Ex indicate intron and exon regions, respectively.

\begin{tabular}{|c|c|c|c|c|}
\hline SNP & Case (DD/Dd/dd) & Control (DD/Dd/dd) & Minor allele frequency & $\mathrm{P}$ \\
\hline $\mathrm{C} 24103249 \mathrm{G}$ & $167 / 21 / 11$ & $164 / 22 / 13$ & $C=0.1143$ & 0.897 \\
\hline A24101991G & $127 / 66 / 6$ & $153 / 43 / 4$ & $G=0.1617$ & $0.0215^{*}$ \\
\hline $\mathrm{C} 24098493 \mathrm{~T}$ & $121 / 69 / 9$ & $131 / 62 / 7$ & $\mathrm{~T}=0.2043$ & 0.603 \\
\hline C24098282G & $117 / 66 / 14$ & $131 / 61 / 8$ & $G=0.2154$ & 0.274 \\
\hline
\end{tabular}

Case $=$ susceptible to salmonellosis; control $=$ resistant to salmonellosis; $\mathrm{d}=$ minor allele; $\mathrm{D}=$ major allele; $\mathrm{DD} / \mathrm{Dd} /$ dd show three genotypes for each locus. $* \mathrm{P}<0.05$.

\section{Tissue-specific expression}

RT-PCR indicated that the chicken Nrampl gene predominantly expressed in liver, thymus and spleen in both males and females, and in male subcutaneous fat and female small intestine, whereas little in gizzard, stomachus glandularis, cloacal bursa, and gonadal tissues in both males and females (Figure 4A). The chicken Nramp2 gene expressed in almost all tissues, but predominantly in breast muscle, leg muscle, cerebrum, cerebellum, lung, kidney, and heart, and relatively less in gizzard, cecum and cloacal bursa in both males and females (Figure 4B). Moreover, the total Nramp2 mRNA level of female chicken was higher than that of males (Figure 4B). 


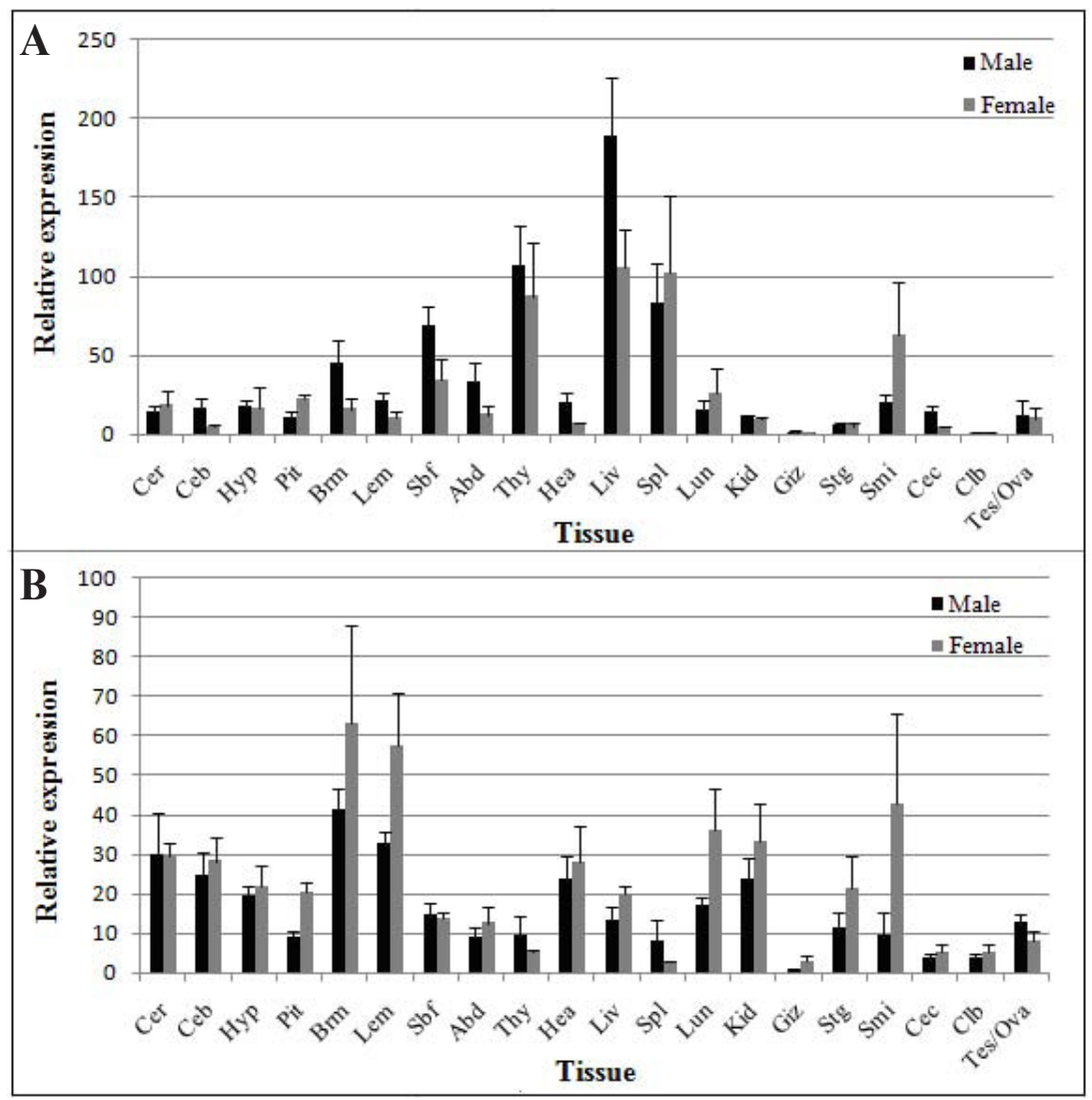

Figure 4. mRNA level of chicken Nramp1 (A) and Nramp2 (B) genes in different tissues. Cer = cerebrum; Ceb $=$ cerebellum; $\mathrm{Hyp}=$ hypothalamus; $\mathrm{Pit}=$ pituitary; $\mathrm{Brm}=$ breast muscle; Lem = leg muscle; $\mathrm{Sbf}=$ subcutaneous fat; $\mathrm{Abd}=$ abdominal fat; thy = thymus; Hea = heart; Liv = liver; Spl = spleen; Lun = lung; Kid = kidney; Giz = gizzard; $\mathrm{Stg}=$ stomachus glandularis; $\mathrm{Smi}=$ small intestine; $\mathrm{Cec}=$ cecum; $\mathrm{Clb}=$ cloacal bursa; $\mathrm{Tes}=$ testis, and Ova $=$ ovary.

\section{DISCUSSION}

In this study, we cloned the cDNA of the Nramp1 and Nramp2 genes in Chinese local chickens. We found two amino acid variations in the Nramp1 gene (Met8Thr and Gly81Ser) and one amino acid variation in the Nramp2 gene (Ala537Val) compared to the reported databases (NP 990295.1 and ABV00877.1). Another study also detected three amino acid variants in six chicken lines with Salmonella-resistant or Salmonella-susceptible phenotypes, namely Thr55Ala, Arg223Gln and Val307Ile (Hu et al., 1997).

Sequence analysis revealed that both Nramp1 and Nramp2 have high homology among all studied species (Figure S1). Similar to that in mammals, the chicken Nramp proteins (both Nramp1 and Nramp2) have 12 conserved TMs and a transport motif between TM8 and TM9, and the functional motifs are very conserved in various species. Moreover, these motifs are also conserved between Nramp1 and Nramp2, especially the first TM (Figure S2). This result is con- 
sistent with previously reported studies (Courville et al., 2006; Lam-Yuk-Tseung et al., 2006).

The expression patterns of the chicken Nrampl and Nramp2 genes are well studied in different tissues of males and females. The Nrampl gene expresses mainly in the phagosomal membrane of macrophages, where inflammatory stimuli, iron, and sodium nitroprusside increase expression (Baker et al., 2000). In this study, we revealed that the chicken Nrampl gene expressed mainly in liver, thymus and spleen by RT-PCR analysis, which was consistent with the reported results by the Northern blot method (Hu et al., 1996). It was previously reported that the levels of the Nramp1 gene in resistant chickens were similar to those in susceptible ones (Hu et al., 1997). The Nramp2 gene widely expresses in a majority of mammalian tissues (Gruenheid et al., 1995; Kishi et al., 1996). Our studies showed that the chicken Nramp2 gene displayed wide expression in almost all tissues, and predominantly in breast muscle, leg muscle, cerebrum, cerebellum, lung, kidney, and heart.

We identified a total of 45 SNPs and 2 indels across the whole chicken Nramp1 gene. Three SNPs lead to amino acid substitutions, namely Arg223Gln, Ala273Glu and Arg497Gln. The mutation Arg223Gln within the predicted TM5-6 region was also detected in chicken, and this allelic variant was specific to the susceptible line $\mathrm{C}$ and not observed in any of the resistant strains (Hu et al., 1997). Another study identified 37 SNPs in 3.1-kb genome region and found that the SNP in male chickens was significantly associated with the antibody level after vaccination and spleen Salmonella load (Liu et al., 2003). In this study, only A24101991G was significantly associated with salmonellosis resistance, and the A allele was advantageous for salmonellosis resistance. This SNP is therefore a potential marker for salmonellosis resistance in poultry production.

\section{ACKNOWLEDGMENTS}

Research supported by the National High Technology Research and Development Program (863) of China (\#2011AA100301 and \#2010AA10A102) and the National Broiler Industry Technology System (\#nycytx-42-G1-04).

\section{Supplementary material}

\section{REFERENCES}

Ates O, Dalyan L, Musellim B, Hatemi G, et al. (2009). NRAMP1 (SLC11A1) gene polymorphisms that correlate with autoimmune versus infectious disease susceptibility in tuberculosis and rheumatoid arthritis. Int. J. Immunogenet. 36: 15-19.

Baker ST, Barton CH and Biggs TE (2000). A negative autoregulatory link between Nrampl function and expression. J. Leukoc. Biol. 67: 501-507.

Barshes NR, Lee TR, Goss JA, Goodpastor SE, et al. (2006). Slc11a1 (formerly Nramp1) polymorphisms and susceptibility to post-transplant lymphoproliferative disease following pediatric liver transplantation. Transpl. Infect. Dis. 8: 108-112.

Blackwell JM and Searle S (1999). Genetic regulation of macrophage activation: understanding the function of Nramp1 (=Ity/Lsh/Bcg). Immunol. Lett. 65: 73-80.

Blackwell JM, Searle S, Goswami T and Miller EN (2000). Understanding the multiple functions of Nramp1. Microbes. Infect. 2: 317-321.

Blackwell JM, Searle S, Mohamed H and White JK (2003). Divalent cation transport and susceptibility to infectious and autoimmune disease: continuation of the Ity/Lsh/Bcg/Nramp1/Slc1la1 gene story. Immunol. Lett. 85: 197-203.

Blasco H, Vourc'h P, Nadjar Y, Ribourtout B, et al. (2011). Association between divalent metal transport 1 encoding gene (SLC11A2) and disease duration in amyotrophic lateral sclerosis. J. Neurol. Sci. 303: 124-127.

Boyer E, Bergevin I, Malo D, Gros P, et al. (2002). Acquisition of Mn(II) in addition to Fe(II) is required for full virulence 
of Salmonella enterica serovar Typhimurium. Infect. Immun. 70: 6032-6042.

Canonne-Hergaux F, Gruenheid S, Ponka P and Gros P (1999). Cellular and subcellular localization of the Nramp2 iron transporter in the intestinal brush border and regulation by dietary iron. Blood 93: 4406-4417.

Canonne-Hergaux F, Calafat J, Richer E, Cellier M, et al. (2002). Expression and subcellular localization of NRAMP1 in human neutrophil granules. Blood 100: 268-275.

Cellier MF, Courville P and Campion C (2007). Nramp1 phagocyte intracellular metal withdrawal defense. Microbes. Infect. 9: 1662-1670.

Cohen A, Nevo Y and Nelson N (2003). The first external loop of the metal ion transporter DCT1 is involved in metal ion binding and specificity. Proc. Natl. Acad. Sci. U. S. A. 100: 10694-10699.

Courville P, Chaloupka R and Cellier MF (2006). Recent progress in structure-function analyses of Nramp protondependent metal-ion transporters. Biochem. Cell Biol. 84: 960-978.

Ganguly I, Sharma A, Singh R, Deb SM, et al. (2008). Association of microsatellite (GT)n polymorphism at 3'UTR of NRAMP1 with the macrophage function following challenge with Brucella LPS in buffalo (Bubalus bubalis). Vet. Microbiol. 129: 188-196.

Gazouli M, Atsaves V, Mantzaris G, Economou M, et al. (2008). Role of functional polymorphisms of NRAMP1 gene for the development of Crohn's disease. Inflamm. Bowel. Dis. 14: 1323-1330.

Gruenheid S, Cellier M, Vidal S and Gros P (1995). Identification and characterization of a second mouse Nramp gene. Genomics 25: 514-525.

Gruenheid S, Canonne-Hergaux F, Gauthier S, Hackam DJ, et al. (1999). The iron transport protein NRAMP2 is an integral membrane glycoprotein that colocalizes with transferrin in recycling endosomes. J. Exp. Med. 189: 831-841.

Gunshin H, Mackenzie B, Berger UV, Gunshin Y, et al. (1997). Cloning and characterization of a mammalian protoncoupled metal-ion transporter. Nature 388: 482-488.

Hu J, Bumstead N, Skamene E, Gros P, et al. (1996). Structural organization, sequence, and expression of the chicken NRAMP1 gene encoding the natural resistance-associated macrophage protein 1. DNA Cell Biol. 15: 113-123.

Hu J, Bumstead N, Barrow P, Sebastiani G, et al. (1997). Resistance to salmonellosis in the chicken is linked to NRAMPI and TNC. Genome Res. 7: 693-704.

Jabado N, Jankowski A, Dougaparsad S, Picard V, et al. (2000). Natural resistance to intracellular infections: natural resistance-associated macrophage protein 1 (Nrampl) functions as a pH-dependent manganese transporter at the phagosomal membrane. J. Exp. Med. 192: 1237-1248.

Jabado N, Cuellar-Mata P, Grinstein S and Gros P (2003). Iron chelators modulate the fusogenic properties of Salmonellacontaining phagosomes. Proc. Natl. Acad. Sci. U. S. A. 100: 6127-6132.

Kishi F, Yoshida T and Aiso S (1996). Location of NRAMP1 molecule on the plasma membrane and its association with microtubules. Mol. Immunol. 33: 1241-1246.

Lam-Yuk-Tseung S, Govoni G, Forbes J and Gros P (2003). Iron transport by Nramp2/DMT1: pH regulation of transport by 2 histidines in transmembrane domain 6. Blood 101: 3699-3707.

Lam-Yuk-Tseung S, Camaschella C, Iolascon A and Gros P (2006). A novel R416C mutation in human DMT1 (SLC11A2) displays pleiotropic effects on function and causes microcytic anemia and hepatic iron overload. Blood Cells Mol. Dis. 36: 347-354.

Leung KH, Yip SP, Wong WS, Yiu LS, et al. (2007). Sex- and age-dependent association of SLC11A1 polymorphisms with tuberculosis in Chinese: a case control study. BMC Infect. Dis. 7: 19.

Liu W, Kaiser MG and Lamont SJ (2003). Natural resistance-associated macrophage protein 1 gene polymorphisms and response to vaccine against or challenge with Salmonella enteritidis in young chicks. Poult. Sci. 82: 259-266.

Mackenzie B and Hediger MA (2004). SLC11 family of $\mathrm{H}+$-coupled metal-ion transporters NRAMP1 and DMT1. Pflugers Arch. 447: 571-579.

Mackenzie B, Ujwal ML, Chang MH, Romero MF, et al. (2006). Divalent metal-ion transporter DMT1 mediates both $\mathrm{H}+$ -coupled Fe2+ transport and uncoupled fluxes. Pflugers Arch. 451: 544-558.

Peracino B, Wagner C, Balest A, Balbo A, et al. (2006). Function and mechanism of action of Dictyostelium Nramp1 (Slc11a1) in bacterial infection. Traffic 7: 22-38.

Rose PP, Hanna SL, Spiridigliozzi A, Wannissorn N, et al. (2011). Natural resistance-associated macrophage protein is a cellular receptor for sindbis virus in both insect and mammalian hosts. Cell Host Microbe 10: 97-104.

Stiles KM and Kielian M (2011). Alphavirus entry: NRAMP leads the way. Cell Host Microbe 10: 92-93.

Tandy S, Williams M, Leggett A, Lopez-Jimenez M, et al. (2000). Nramp2 expression is associated with pH-dependent iron uptake across the apical membrane of human intestinal Caco-2 cells. J. Biol. Chem. 275: 1023-1029.

Touret N, Furuya W, Forbes J, Gros P, et al. (2003). Dynamic traffic through the recycling compartment couples the metal transporter Nramp2 (DMT1) with the transferrin receptor. J. Biol. Chem. 278: 25548-25557.

Trinder D, Macey DJ and Olynyk JK (2000). The new iron age. Int. J. Mol. Med. 6: 607-612. 
Vidal SM, Malo D, Vogan K, Skamene E, et al. (1993). Natural resistance to infection with intracellular parasites: isolation of a candidate for Bcg. Cell 73: 469-485.

White JK, Stewart A, Popoff JF, Wilson S, et al. (2004). Incomplete glycosylation and defective intracellular targeting of mutant solute carrier family 11 member 1 (Slc11a1). Biochem. J. 382: 811-819.

Wu H, Cheng D and Wang L (2008). Association of polymorphisms of Nrampl gene with immune function and production performance of Large White pig. J. Genet. Genomics 35: 91-95.

Xue R, Wang S, Qi H, Song Y, et al. (2009). T178 deletion impairs intermolecular interaction of the peptide Nramp1(164-191). J. Pept. Sci. 15: 377-384.

Yang JH, Downes K, Howson JM, Nutland S, et al. (2011). Evidence of association with type 1 diabetes in the SLC11A1 gene region. BMC Med. Genet. 12: 59 . 